Journal of Social Sciences (COES\&RJ-JSS)

ISSN (E): 2305-9249 ISSN (P): 2305-9494

Publisher: Centre of Excellence for Scientific \& Research Journalism, COES\&RJ LLC

Online Publication Date: $1^{\text {st }}$ April 2017

Online Issue: Volume 6, Number 2 Special, April 2017

http://centreofexcellence.net/J/JSS/JSS\%20Mainpage.htm

\title{
Effects of using Video Vignette on Pre-service Teachers' Pedagogical Content Knowledge and Views in Teaching
} Norhayna Eryll M. Unte

Secondary Teaching Department, College of Education, Mindanao State University, Marawi City

\begin{abstract}
:
Any attempt to improve the quality of basic education should first focus on improving the quality of pre-service teachers' characteristics which embrace pedagogical content knowledge (PCK) and views in the teaching-learning process. In the course of doing this, the use of interactive technology e.g. video vignette could be a measuring tool.This study investigated the effects of using video vignette in pedagogical content knowledge and views in teaching and learning of pre-service teacher. From the analysis of data, the results showed that there is a significant difference in the level of the twenty-three pre-service teachers' pedagogical content knowledge in terms of knowledge of the subject matter, knowledge of learners, knowledge of curricula and knowledge of general pedagogy enrolled during $2^{\text {nd }}$ semester of 2013-2014 in MSU-College of Education. Moreover, the study also revealed various views in teaching science/mathematics as profession, how to teach science in a traditional and contemporary approach, and how students learn best. Responses by the respondents suggest that video vignette genuinely reflect the actual classroom experience and investigate individual's ethical principles and behavior in the context of teaching. Additionally, video vignette served as a potential means to monitor and evaluate teacher education courses for professional development.
\end{abstract}

Keywords:

Video, vignette, pre-service teachers, pedagogy, content knowledge

Citation:

Unte, Norhayna Eryll M. (2017); Effects of using Video Vignette on Pre-service Teachers' Pedagogical Content Knowledge and Views in Teaching; Journal of Social Sciences (COES\&RJ-JSS), Vol.6, No.2 Special, pp: 81-86. 


\section{Introduction}

More than any profession, teaching is the chief transmitter of culture is, is affected by this state of flux, hence, the importance of teacher education. It cannot be taken uncritically. The fundamental question rose regarding teacher education or any kind of human resource development, for that matter is: Did the training transfer to the students? Have they taken or imbibed the knowledge, skills, attitudes and abilities supposed to be learned in the training situation? All these questions compel critical attention to teacher education, specifically pre-service training.

In the Philippines, the pre-service preparation of teachers for the primary and secondary education sectors is a very important function and responsibility that has been assigned to higher education institutions. All efforts to improve the quality of education in the Philippines are dependent on the pre-service teachers who are properly prepared to undertake the various important roles and functions (Experiential Learning Courses Handbook, 2007 p. 10).

Viewing the importance of teacher competency and their roles in educating the youth as a kind of article of faith, the researcher herself has an apprehension that pre-service teachers' characteristics which embrace pedagogical content knowledge (PCK) and views on the teaching-learning process may not be informed by, or does not reflect the future's thrust in attaining quality education. Lee Shulman defined pedagogical content knowledge (PCK) as cited by Solis (2009) and Magdara (2012) as teachers' interpretations and transformations of subject-matter knowledge in the context of facilitating student learning. PCK represents the blending of content and pedagogy into an understanding of how particular aspects of subject matter are organized, adapted, and represented for instruction.

The researcher had a flash of insight: Why not use modern interactive technology, particularly video vignette, in gauging or measuring the effect of practice teaching course on pre-service teachers' pedagogical content knowledge (PCK) and views on teaching and learning? The insight was admittedly an upshot of the researcher's five-year teaching experience. Ever since, the researcher has made use of interactive technology and it is her yearning to employ video vignette to measure the pedagogical content knowledge and views in teaching among pre-service teachers. Studies show that utilizing vignettes to measure instructional practices in arithmetic classrooms conducted by the RAND Corporation (Stecher, et al., 2006) offers cautious support for this format as a valid means of measuring behaviors that are consistent with what is found in classroom observations and on surveys and logs cited by Barnatt, et al. (2007).

From the abovementioned principles and theories of learning, the researcher inferred that video vignette may have an effect on the pre-service teachers' pedagogical content knowledge and views on teaching and learning. Prior to the intervention the pre-service teachers were assessed based on their pedagogical content knowledge and views on teaching. Then a vignette in the form of a video excerpt that recorded or captured the teaching practices and competencies of pre-service teachers was shown to the respondents (trainees). This is followed by an evaluation intended to determine the effect of the video on the pre-service teachers' pedagogical content knowledge and views on teaching. 


\section{Materials and Methods}

The study utilized both the quantitative and qualitative methods of research to determine the effect of video vignette on the pre-service teachers' pedagogical content knowledge and their views on teaching and learning. The quantitative part of the study focused on determining the effect of the intervention, that is, the use of video vignettes, on pre-service teachers' pedagogical content knowledge (PCK), by measuring or ascertaining the difference in the level of competency before and after intervention, in the four domains of pedagogical content knowledge, namely knowledge of subject matter, knowledge of learners, knowledge of curricula, and knowledge of general pedagogy. The qualitative part was devoted to exploring the pre-service teachers' views about teaching and learning before and after the intervention and the respondents' perceptions on the use of video vignette as data for analysis, reflection and assessment in their practice teaching course. For greater validity of data and findings drawn from them, classroom observations, written reflections and responses during interviews were used to cross validate the results.

Statistical analyses were performed on the data obtained through the competency-based performance rating made during their classroom teaching. A t-test was employed in determining the significant difference before and after the intervention. These data were computed and analyzedusing SPSS for MS windows and set at 0.05 level of significance. Classroom observations were further done by the researcher for purposes of triangulation, that is, to ensure validity of the results.

\section{Results and Discussions}

The first essential aspect of teaching is that the teacher must have a thorough grasp of the subjects he teaches (Lardizabal, et al., 2002). As future teachers, pre-service teachers are expected to concentrate in their field or the subject they teach. As shown in Figure 1 is the pre-service teachers' knowledge of the subject matter, somehow reflect significant improvement in the pre-service teachers' knowledge of the content or subject matter they taught. It may be inferred that before intervention, they were still struggling to cope with, that is, fully grasp the content of the given subject and unexpected tasks given to them by their cooperating teachers.

Figure 1

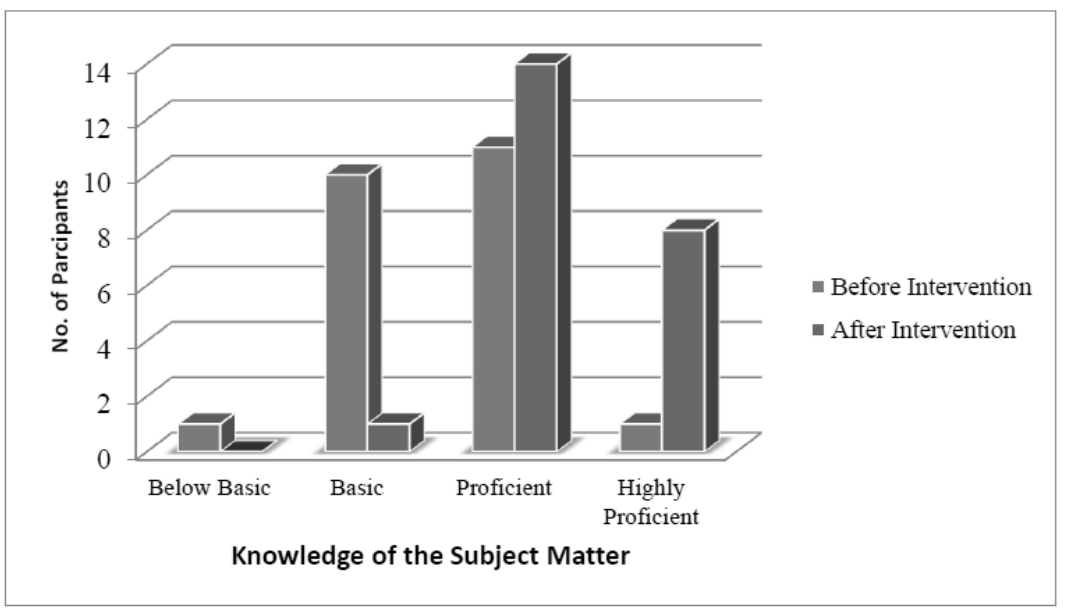


The second essential aspect of teaching is knowledge of children. Pre-service teachers must know the interests and needs, previous experiences of their students, and their ability levels and learning strategies, to guide learning effectively. Equally important is, they must like them. As revealed in Figure 2, there is a significant difference in the level of PCK in terms of the pre-service teachers' knowledge of learners.

Figure 2

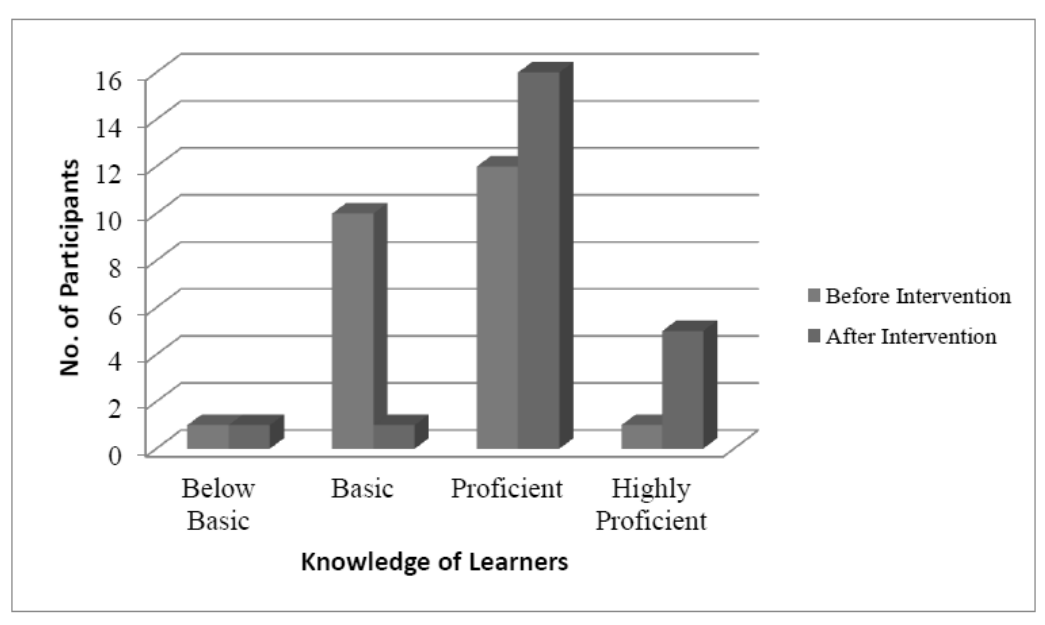

Pre-service teachers must understand the curricular goals and objectives, and attain high standards of learning defined in the curriculum. Their performance in relation to this aspect is shown in Figure 3 reveals that there was discernible improvement in the domain under consideration. Because of the previous experience regarding the respective subject's curricula in the secondary level, the pre-service teachers gained familiarity or even mastery of the content to be taught in the respective year level.

Figure 3

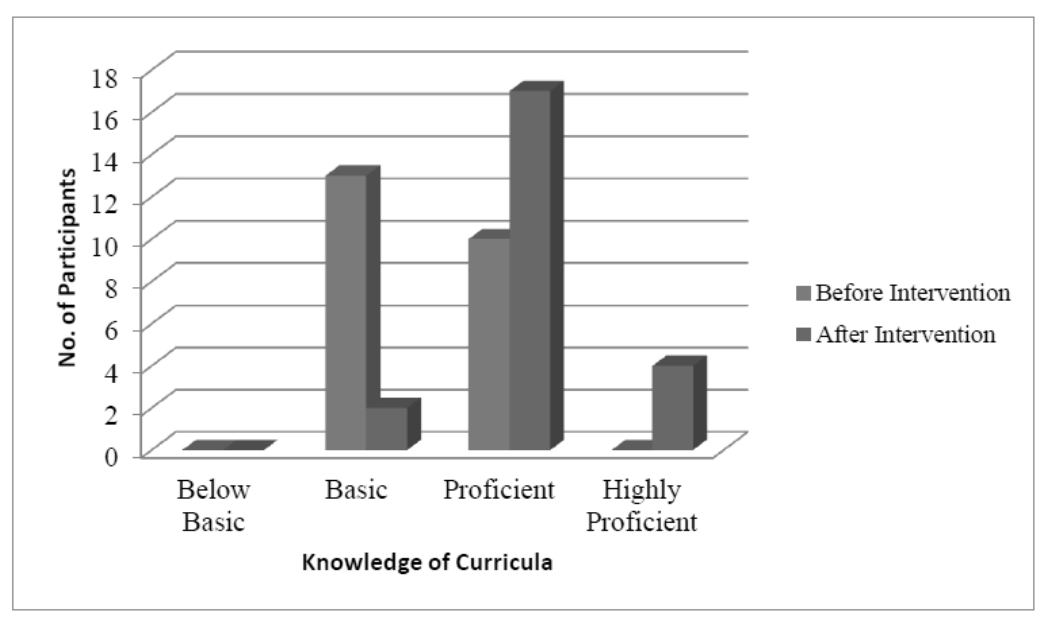


To promote learning effectively, a teacher must know not only what (subject matter) but also how (method) to teach (Lardizabal, et al., 2002). As can be gleaned from the data set out in Figure 4, there is concentration or crowding of the respondents in the higher levels highly proficient and proficient. Two who failed to edge their way to these levels, were at least still assessed as of basic proficiency.

Figure 4

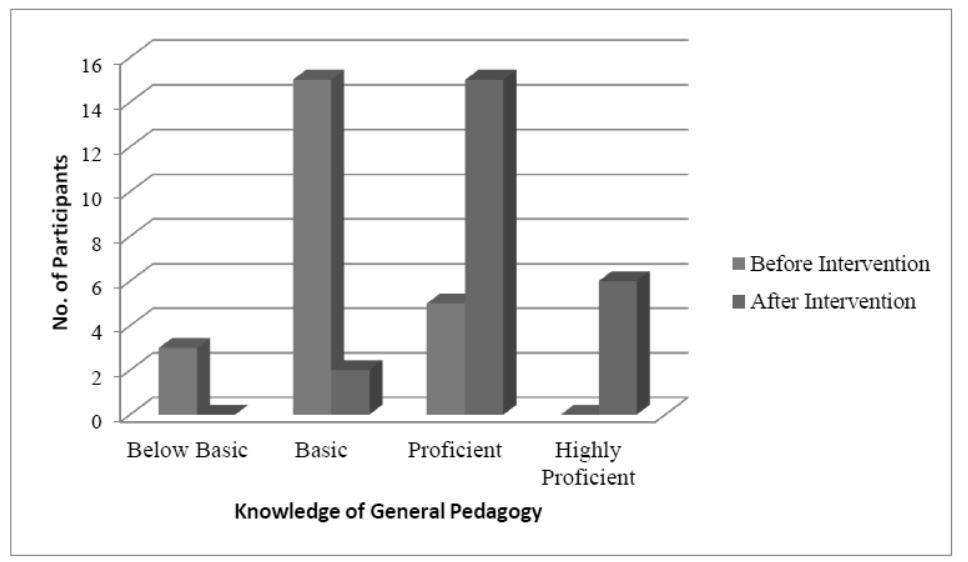

Added up, the results of the analysis of data indicated that video vignette is useful as a teacher training resource. After their exposure to the video vignette, the pre-service teachers demonstrated higher ratings or levels on the competency-based performance rating instrument. Many respondents were promoted from the basic to the proficient level, and a significant increase of number within the highly proficient level in the four aspects of pedagogical content knowledge was registered. The difference in the level of competency before and after the intervention was found to be significant; hence, the null hypothesis was rejected. Qualitative analysis of the participants' responses in interviews and their written reflections revealed a significant change in the views on teaching and learning, of the pre-service teachers.

\section{Conclusion}

Based on the findings of the study, it is concluded that video vignette is powerful teaching tools in developing pre-service teachers proficiency and probably same as true to the learners. This teacher training resource helps promote the teachers competency and enhance the teacher's pedagogy and content knowledge. Thus, it is recommended that this type of teacher training resource will be used in the training and teaching course among pre-service teachers and among in-service teachers.

\section{References}

Anderson, L.M. \& Holt-Reynolds, D. "Prospective teachers' beliefs and teacher education pedagogy research based on a teacher educators' practical theory." Retrieved March 27, 2005.fromhttp://ncrtl.msu.edu.

Chong, Sylvia, Wong, Isabella \&Choon Lang, Quek. "Pre-service teachers' beliefs, attitudes and 
expectations: A Review of the Literature." National Institute of Education, Nanyang Technological University.Retrieved January 30, 2012.

Cullen, Richard (1989). "Video in teacher training: the use of local materials." ELT Journal, Volume

45/1, January 1991. London: Oxford University Press in association with The British Council and with IATEFL.

Enfield, Mark. "Content and pedagogy: intersection in the NSTA standards for science teacher education.” Michigan State University.Retrieved January 14, 2012.

Ergul, Remziye N. (2009). "Elementary pre-service teachers" opinions on teaching science." Bulgarian Journal of Science and Education Policy (BJSEP), Uludağ University, TURKEY, Volume 3.

Experiential learning courses handbook (2007). "A project of Teacher Education Council (TEC)," Department of Education (DepEd) and Commission on Higher Education (CHED).

Koehler, Dr Matthew J. Pedagogical Content Knowledge. Retrieved May 13, 2011. www.mkoehler.educ.msu.edu.

Morrison, R.L., Stettler, K., \& Anderson, A.E. (2004). "Using vignettes in cognitive research on establishment surveys.” Journal of Official Statistics. 20 (2), 319-340.

National Competency Based Standards (July 2009).

"Pedagogical Content Knowledge in Science Teaching."Retrieved February 2, 2012.www.csun.edu.

Pagaduan, Caridad Ed.D (2009). “Academic performance in selected field study courses and off-campus teaching competence of pre-service teachers." University of the Cordilleras, Baguio City, Philippines Vol. 01 No.4.

Penso, Sophia (November 2002). "Pedagogical Content Knowledge: how do student teachers identify and describe the causes of their pupils' learning difficulties?" AsiaPacific Journal of Teacher Education, Vol. 30, University of Haifa, Israel. Retrieved January 20,2012.

Prudente, Maricar S. \&Aguja, Socorro E. "Science Teaching/Learning Processes in Preservice Teacher Education: The De La Salle University-Manila Experience." De La Salle University, Philippines.Retrieved Septembe11, 2011.

Tabanao, Manolito (March 2005) M. "Audio-Video assisted Instruction: Effects on high school students' concepts and achievement in Physics." Unpublished masteral thesis.

Sasson, Dorit ( July 27, 2007). "What makes a good teacher begins during pre-service teaching years." Retrieved January 15, 2012 from http://doritsasson.suite101.com.

Van Driel, J. H, Verloop, N., \&DeVos, W. (1998). "Developing science teachers' pedagogical content knowledge." Journal of Research in Science Teaching, 35(6), 673695.

Veal, William R (2002).“Content Specific Vignettes as Tools for Research and Teaching." University of North Carolina Chapel Hill Electronic Journal of Science Education, Vol. 6, no. 14.

Veal, Wiliam and MaKinster, James (1999).Pedagogical Content Knowledge Taxonomies. 